\title{
Design elements of innovation contests supporting Open Innovation in SMEs - An action research study
}

\author{
Nicola Doppio \\ nicola.doppio@trentinoinnovation.eu | Hub Innovazione Trentino \\ Satu Väinämö \\ satu.vainamo@oulu.fi| Centre for Health and Technology, Faculty of Medicine, University of Oulu, \\ Finland \\ Lotta Haukipuro \\ lotta.haukipuro@oulu.fi| University of Oulu, GenZ project
}

\begin{abstract}
While Open Innovation contests and intermediaries are widely adopted in large companies to source knowledge from the outside, it is not clear to what extent contests can help break down the barriers that SMEs face in pursuing Open Innovation. In this paper, we present the results of an action research study pivoting on an analysis of ten innovation contests that were successfully run in three European countries. The contests aimed to identify innovation opportunities through interaction of SMEs with higher education institutions, research centers, other companies, or end-users. The findings suggest that innovation contests can be viable instruments for SMEs to implement Open Innovation support policies. In particular, our analysis uncovered some structural elements and design options for contests that had been overlooked in previous research. On this basis, and considering the practical aim of the study, the paper presents a new framework of twelve components that can be used by innovation intermediaries for the development of innovation contests specifically designed to enable Open Innovation in SMEs.
\end{abstract}

Keywords. Open Innovation; SMEs; Small and Medium-Sized Enterprises; Innovation Contests; Innovation Prizes; Innovation Challenges; Innovation Agencies; SME Innovation Policy; Design Canvas; New Product Development.

Cite paper as: Doppio, N., Väinämö, S., Haukipuro, L., (2020). Design elements of innovation contests supporting Open Innovation in SMEs - An action research study, Journal of Innovation Management, www.open-jim.org, $8(4), 26-56$. 


\section{Introduction}

Innovation contests (a.k.a. innovation prizes) have been utilized for centuries by governments to spark innovation and solve so-called "grand challenges", i.e. complex technological problems that, if solved, could impact society as a whole (Murray et al., 2012; Scotchmer, 2006). In addition to enabling large institutions (the so-called "seekers") to source innovation from the outside (Lakhani, 2006), scholars have observed how prizes positively influence competing actors (the so-called "solvers", normally companies or professionals) to come up with the best solutions. As a result, they are now recognized as viable instruments for implementing innovation policies in companies (Burstein \& Murray, 2016; Kay, 2012; Liotard \& Revest, 2018; Tödtling \& Trippl, 2005; Williams, 2012).

In more recent years innovation contests have been utilized by large companies to engage suppliers, clients, and partners in inbound Open Innovation (OI) processes (Chesbrough, 2003, 2010; Chesbrough \& Kardon Crowther, 2006; Piller \& Walcher, 2006; West \& Bogers, 2014). Nowadays, corporate OI contests are often intermingled with academic initiatives and tech community events like hackathons (Briscoe \& Mulligan, 2014). Web-based platforms and intermediaries offering OI services to companies have also emerged (Chesbrough, 2010; Gassmann \& Enkel, 2004).

In the light of these developments, the European Commission has urged public innovation agencies to experiment with new innovation support programs for SMEs that leverage the traits of innovation prizes and contests (European Commission, 2009a). Recently, the European Commission's Executive Agency for Small and Medium-Sized Enterprises (EASME) has funded specific coordination and support actions within the scope of the H2020 research and innovation Work Programme. These aim to enhance the capacity of innovation agencies to design, pilot, and validate new SME-innovation support initiatives based on the innovation contest format (see for example the INNOSUP-05 and INNOSUP-06 project calls) (European Commission, 2018b).

Research has shown that Open Innovation works very differently in SMEs (Small and MediumSized Enterprises) rather than LEs (Large Enterprises) (Brunswicker \& Vanhaverbeke, 2015; Chiaroni et al., 2011; Usman et al., 2018), and it is still not clear to what extent innovation contests can be effectively utilized to support and possibly mediate OI in SMEs. It is also not clear whether the many theoretical frameworks currently available in literature describing the main characteristics and operation of innovation prizes and contests - ranging from the seminal Murray et al. (2012) to the more recent Rodriguez Ferradas, Alfaro Tanco and Sandulli (2017) - can be effectively utilized by public innovation agencies to design and run innovation contests specifically aimed to support SMEs.

The purpose of this exploratory study is to provide an initial understanding of innovation contests as appropriate instruments for supporting OI in SMEs. We aim to shed light on two specific research questions: (1) whether innovation contests can help break down the barriers that SMEs face in pursuing OI; and (2) how innovation contests should be designed and structured to achieve this goal. In addition to answering these questions, we also have the practical purpose of enhancing the capacity of innovation agencies and actors in the design and management of innovation contests supporting OI in SMEs. 
Considering the theoretical and practical goals of the study, the action research methodology was chosen (Lewin, 1946), since it facilitates the development of theory while solving real-world problems. Of the latter, we sought to address the lack of a usable framework for actors trying to implement innovation contests for SMEs. The practical goal of our action research was to design and deliver a viable tool (canvas) for SME innovation management actors that would allow them to realize innovation contests capable of enabling OI in SMEs.

Our findings support the case for innovation contests as valid instruments for breaking down the barriers that SMEs currently face when pursuing OI. Our research builds on a sound corpus of qualitative field data delineating in-depth descriptions of ten innovation contests. This enabled us to identify a specific set of design elements that innovation contests should include in order to best impact SMEs. We structured these elements into a novel framework comprising 12 design elements: this represents an innovation contest design canvas, which we propose as a useful tool for relevant actors.

Our discussion includes a thorough review of related work, illustrating the specific needs and barriers that SMEs face when pursuing OI, along with the necessary conditions for successfully implementing SME OI support policies. We present various types of innovation contests, their operation and structural elements, and the currently available evidence for their impact on the OI capacity of companies.

\section{Related work}

\subsection{Open Innovation in SMEs: barriers, constraints, and policy require- ments}

Open Innovation (OI) refers to the capability of firms and other organizations to engage with external parties (customers, suppliers, partners) in order to generate and incorporate knowledge, IP (Intellectual Property), or other innovation-related input (e.g. technology) with the aim of increasing their capacity to develop competitive products (Chesbrough, 2003, 2009). Open Innovation is now widespread in companies, and innovation scholars have also embraced the concept (Chesbrough, 2014). SMEs are more dependent than LEs on their capacity for rapid product innovation to sustain competitiveness (Parida et al., 2012), and consequently the importance and efficiency of OI for them has become a subject of research (Greco et al., 2017).

At the same time, research shows how OI processes in SMEs differ from those in LEs for a number of reasons. Firstly, SMEs face many obstacles to innovation: they have more limited financial resources and less time available for internal R\&D; they lack innovation management skills and structures; they have a more limited action and networking range $(60-100 \mathrm{~km})$; they operate on shorter time scales to capture results; and they have difficulty collaborating with academic institutions (Brunswicker \& Vanhaverbeke, 2015; Chiaroni et al., 2011; Usman et al., 2018). They stand to gain particularly large benefits from sourcing insights into new business opportunities beyond their existing products and markets derived from indirect customers and end-users (Brunswicker \& Vanhaverbeke, 2015). Finally, they are less aware of the benefits of OI (Chesbrough \& Vanhaverbeke, 2018). Overall, existing research agrees that the lessons learned 
from OI in large firms cannot be transferred directly to SMEs (Chesbrough \& Vanhaverbeke, 2018).

In relation to these barriers, research further suggests that OI could be facilitated in SMEs, which has implications for policymaking. One way to positively influence OI in SMEs is to improve their absorptive capacity, which can be defined as their capacity to recognize the value of new information, assimilate it, and apply it for commercial ends (Cohen \& Levinthal, 2000; King \& Lakhani, 2011; Zahra \& George, 2002). This can be promoted via non-monetary support activities like networking (Brunswicker \& Vanhaverbeke, 2015) and awareness-raising (Chesbrough \& Vanhaverbeke, 2018). Research has further demonstrated that OI in SMEs can benefit from their local business culture context, the RIE (Regional Innovation Ecosystem). This includes proximity and close relationships between companies and the higher education system (Chesbrough \& Vanhaverbeke, 2018; Oliveira et al., 2017), and shifting support from individual firms to the RIE as a whole (Chesbrough \& Vanhaverbeke, 2018; Cooke, 2001; Tödtling \& Trippl, 2005). Another policy suggestion for supporting OI in SMEs is strengthening the role of regional innovation intermediaries. Intermediaries appear to play a crucial role in facilitating OI within SMEs (Katzy et al., 2013): they can support SMEs in establishing partners, and fulfill innovation management functions by activating initiatives on an RIE level (Lee et al., 2010; Oliveira et al., 2017). Another recommendation worth recalling on SME innovation policy design comes from the European Commission and regards the manner in which innovation agencies should undertake policy design and experimentation: the advice is to "think small first", in other words design new policy instruments that can be piloted and evaluated with limited costs within short to medium time frames (European Commission, 2008, 2009a, 2018a).

\subsection{Innovation contests and their structural elements}

Innovation prizes (a.k.a. inducement prizes) are initiatives that offer incentives for advancing research and technology by addressing unsolved innovation problems, often impacting society as a whole (Gök, 2016; Murray et al., 2012; Scotchmer, 2006). Innovation prizes have traditionally been advanced by governments to achieve technological leaps, address major societal challenges, or develop generic technologies (Adamczyk et al., 2012; Kalil, 2006; Kokshagina et al., 2017; Masters \& Delbecq, 2008). Prizes may be defined according to different objectives, design options, and performance evaluation methods, the so-called prize dimensions (Murray et al., 2012). There might also be structural elements, defined in various ways according to circumstances: type of reward, competition, rules, intellectual property clauses, and so on (Liotard \& Revest, 2018).

Innovation prizes (often referred to as innovation contests, or challenges) are also organized by businesses with the involvement of customers, technology experts, or suppliers with the aim of supporting new product development (NPD), (Chesbrough, 2003, 2010; Piller \& Walcher, 2006; West \& Bogers, 2014). Innovation contests are defined as time-limited competitions arranged by an organization that calls on the general public or a specific target group to make use of their expertise, skills or creativity in order to submit a solution for a particular task defined by the organizer, who is seeking an innovative solution and offers participants certain incentives (Terwiesch \& Xu, 2008). Both prizes and contests connect so-called seekers of innovation (those 
with a problem or an innovation demand, normally companies), with those who can provide innovations, the so-called solvers, who compete for a specific prize or benefit (Chesbrough, 2010; Lakhani, 2006; Terwiesch \& Xu, 2008).

Innovation contests can focus on basic ideas, when the outputs are ideas for new products or business opportunities (Piller \& Walcher, 2006). Alternatively, they can be community-based contests (Bullinger et al., 2010; Bullinger \& Moeslein, 2010; Kathan et al., 2014) that leverage communities of participants passionate about a particular technology, or a specific problem, either off-line or online (Adamczyk et al., 2012). For example, hackathons are digital innovation contests specifically dedicated to ICT challenges that involve coding and delivering software prototypes or algorithms (Briscoe \& Mulligan, 2014; Hjalmarsson \& Rudmark, 2012).

Many factors influence the outcome of OI contests, like the number of participants (Boudreau et al., 2011), the variety of backgrounds of participants (Armisen et al., 2015), cultural proximity of participants (Bockstedt et al., 2015), and participant self-selection (Mack \& Landau, 2015). More generally, literature demonstrates that the overall operation of an innovation contest is influenced by a number of design elements (Piller \& Walcher, 2006). Based on a review of different idea contests, Bullinger and Moeslein (2010) distinguish ten key elements in idea contest design, including: media (online, offline), profile of organizer (company, PA), specificity of task/topic, duration, type of reward, and so on. In addition to Bullinger and Moeslein (2010), Hjalmarsson and Rudmark (2012) provide four more complementary design elements relevant to appropriate design and management of digital innovation contests: requirements, value, data, novelty. Adamczyk, Bullinger and Möslein (2012) provide five more design elements, extending the list to 15 items. Rodriguez Ferradas, Alfaro Tanco and Sandulli (2017) focused on the innovation contest design elements that were relevant as managerial instruments specifically intended to support SMEs, proposing a more comprehensive theoretical framework based on 20 factors or design elements (see Figure 1).

\subsection{Innovation contests as Open Innovation policy instruments for SMEs}

Innovation prizes have been used by public or publicly funded innovation agencies and intermediaries to engender Open Innovation, and they are now recognized and studied as an innovation policy instrument (Burstein \& Murray, 2016; Kay, 2012; Liotard \& Revest, 2018; Tong \& Lakhani, 2012; Williams, 2012). Prizes are described as instruments for use by public administrations to facilitate development of new potential public service ideas and prototypes (Chesbrough \& Vanhaverbeke, 2018). In addition, research suggests that prizes and contests can be additional tools for promoting innovation within companies, alongside more traditional innovation inducement policies like tax reductions and direct funding (Makkonen \& Inkinen, 2014).

According to Liotard and Revest (2018), prizes can generate favorable knowledge spillovers in the wake of contests, producing innovation and economic gains in specified economic/industrial sectors. They may also play a beneficial social role, educating and raising awareness of citizens. Mäkelä (2017) points out that innovation prizes bring about other benefits, like enabling beneficiaries to identify talents and investment opportunities. At the same time, innovation contests like hackathons can produce intangible benefits that impact the OI capacity of companies: 


\begin{tabular}{ll}
\hline Design element & Attributes \\
\hline Media & Online - mixed - offline \\
Organizer & Company - public organization - non-profit - individual \\
Task/topic specificity & Low (open task - defined - high (specific task) \\
Degree of elaboration & Idea - sketch - concept - prototype - solution - evolving \\
Target group & Specified - Not specified \\
Participation & Individual - team - both \\
Contest runtime & Very short term - short term - long term - very long term \\
Reward/motivation & Monetary - non-monetary - mixed \\
Community functionality & Given - not given \\
Evaluation & Jury - peer review - self assessment - mixed \\
Attraction & Online - offline - mixed \\
Facilitation & Professional facilitation - peer facilitation - mixed \\
Sponsorship & Family - friends and colleagues - universities \\
Contest phases & One - two - more \\
Replication cycles & Biannual - annual - less frequent - more frequent \\
Number of participants & High - low \\
Difference in participant backgrounds & Different profiles - similar profiles \\
Participatory dynamics & Add their own - argue with others \\
Degree of cultural similarity among participants & Different - similar \\
Participant self-selection & Compulsory - optional \\
&
\end{tabular}

Fig. 1. Design elements and options (attributes) of innovation contests for SMEs, according to Rodriguez Ferradas, Alfaro Tanco and Sandulli (2017).

hackathons provide individuals with valuable experience, networking, and training, while simultaneously fostering a more cohesive working community, enhancing awareness of challenges and best practices, and building bridges of familiarity between resources and people (Stoltzfus et al., 2017).

According to Liotard and Revest (2018), given their design flexibility, innovation prizes work well as instruments for innovation intermediaries who want to induce collaboration between diverse innovative players and establish industrial/research partnerships. However, it remains unclear to what extent innovation contests can be utilized by public innovation intermediaries as instruments to break down barriers faced by SMEs embarking in Open Innovation, and thus whether they should be indicated by policymakers as SME innovation policy instruments.

\section{Methodology}

\subsection{Overall approach}

Given the research questions and goals, this study applied the action research method. Action research, introduced by Lewin (1946), is intended to produce relevant results in the solution of concrete problems, while also informing theory. It emphasizes interaction between theory and 
practice, and typically involves multiple stakeholders with varying roles (Baskerville \& WoodHarper, 1996, 1998; Checkland \& Holwell, 1998; Jönsson, 1991). According to Baskerville \& Wood-Harper (1996), action research is one of the few valid research approaches that can legitimately be employed to study the effects of specific alterations in system development methodologies. Both the object and level of change pursued by action research can differ: the object of change can range from knowledge (e.g. training to develop skills) to the introduction of new methods and practices in a team; levels of change can range from individuals, to teams, to whole organizations (Guertler et al., 2020).

Action research has been applied in many disciplines, including Technology Innovation Management (TIM) (Guertler et al., 2019), which is particularly suited to the application of action research, since this makes it possible to address its multifaceted and socio-technical aspects, high level of novelty and uncertainty, and broad range of stakeholders involved (Guertler et al., 2020). Within this context, we adopted the Action Innovation Management Research (AIM-R) approach and process model, recently proposed by Guertler et al. (2020). It entails the following phases: (1) Analysis and framing, (2) Project planning, (3) Execution of action, (4) Reflection and learning, and (5) Communication and pivoting.

Our study methodology was also informed by the concepts of Design Science and Design Science Research (Gregor \& Hevner, 2013; Kuechler \& Vaishnavi, 2008; Sein et al., 2011), which apply to action research projects with an engineering scope. These aim to design, develop, and introduce artefacts, processes, or products into an organization. In this respect, Peffers, Tuunanen, Rothenberger, \& Chatterjee (2007) propose a process model for action research projects aimed at developing information systems (IS), stressing distinctive steps of designing and developing a solution, and then demonstrating or testing its applicability inside the organization. This approach fits our action research study, because its final aim is the introduction of a new artifact (a tool for designing innovation contests).

\subsection{The action research process implemented in this study}

Following the abovementioned five-phase AIM-R process model proposed by (Guertler et al., 2020), we organized and executed our action research as follows:

1) Analysis and framing. In this phase we developed our research questions and goals; we analyzed the relevant literature and currently available practices in innovation contests for SMEs. This phase resulted in the preparation and acquisition of project grant funding for our research ${ }^{1}$. The outcomes of this phase are covered in Section 2.

2) Project planning. In this phase we created the overall design of the study: our intention was essentially to collect a number of innovation contest examples across Europe that had been successful in supporting SMEs. To achieve this, we first developed a data collection tool (template) that would serve as an initial version of the canvas we wanted to deliver. The template was used to collect data about existing innovation contests in order to field-test its viability and collect comparable data about the structure (design elements) of the analyzed contests. The plan included workshop sessions to present both the template and the example cases to practitioners

1 H2020 INNOSUP-05 project n. 804454 "INNOCHALLENGE" (https://cordis.europa.eu/project/id/804454). 
Table 1. Data collected during the action research process.

\begin{tabular}{|c|c|c|}
\hline DATA SET & TYPE & SOURCE \\
\hline $\begin{array}{l}\text { 1. Innovation contest } \\
\text { case descriptions }\end{array}$ & $\begin{array}{l}\text { Qualitative, first level: structured } \\
\text { interviews based on common tem- } \\
\text { plate }\end{array}$ & $\begin{array}{l}10 \text { managers of innovation } \\
\text { contests }\end{array}$ \\
\hline $\begin{array}{l}\text { 2. Innovation contest } \\
\text { case interpretations }\end{array}$ & $\begin{array}{l}\text { Qualitative, } \\
\text { annotations from internal dis- } \\
\text { cussions }\end{array}$ & Research team \\
\hline $\begin{array}{l}\text { 3. Innovation contest } \\
\text { case interpretations }\end{array}$ & $\begin{array}{l}\text { Qualitative, first level: annotations } \\
\text { from three one-day workshops }\end{array}$ & $\begin{array}{l}48 \text { managers of innovation } \\
\text { contests and other innova- } \\
\text { tion management practiti- } \\
\text { oners }\end{array}$ \\
\hline $\begin{array}{l}\text { 4. Workshop feedback } \\
\text { interpretations }\end{array}$ & 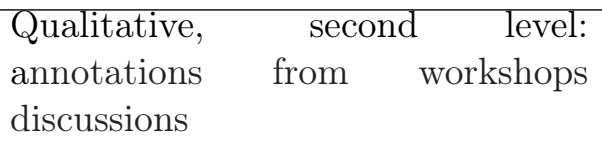 & Research team \\
\hline
\end{tabular}

(potential users) in order to elicit feedback as further input to the canvas design process. During this phase, we also developed detailed requirements for the selection of innovation contest examples. This phase was completed with the development of a template capable of collecting structured information about the innovation contests. This last sub-phase matches phase 3 of the Peffers et al. (2007) process model for the "Design and development" of the system. The results of this phase are presented in Sections 3.3 and 4.1.

3) Execution of action. This phase included the following actions: i) selection and collection of the contest examples using the developed template - ten examples were selected and the data collected by three research teams through structured interviews of the innovation contest managers; ii) once the examples had been collected, the different research team members presented each of them in turn in order to establish a detailed understanding and interpretation of all the examples; iii) next, the example cases together with the template were presented to practitioners during three one-day workshops hosted by the research team in three countries in order to generate feedback both on the examples and the template. This phase matches phase 4 of the Peffers et al. (2007) process model for the "Demonstration" of the developed system. All these processes (detailed in Sections 4.2 and 4.3) allowed us to develop a substantial corpus of qualitative data, as listed below in Table 1.

4) Reflection and learning. This phase matches phase 5 of the Peffers et al. (2007) process model for the "Evaluation" of the developed system. In this phase the collected data were analyzed for both theoretical and practical purposes. The theoretical aim involved a comparative analysis of the ten example innovation contests in order to seek answers for our two research questions. On a practical level, we sought to extract concrete results from the data in order to evaluate the viability of the applied template, improve it, and ultimately refine it into our final canvas. The two analyses and related findings are presented separately in Sections 4.3. and 4.4. The fact that we could count on four separate data sets enabled data triangulation to increase the reliability of the findings (Denzin, 1973; Eisenhardt, 1989). Triangulation refers to the use of multiple methods or data sources in qualitative research to develop a comprehensive understanding of 
phenomena (Patton, 1999). Triangulation is also regarded as a qualitative research strategy to test validity through the convergence of information from different sources. The principle applied in the data analysis was to systematically seek connections, recurrences, and differences within the data and identify recurrent features and patterns across cases on an item level.

5) Communication and pivoting. During this final phase (presented in Sec. 4.5) we applied the insight developed in the previous phase to improve and evolve the data collection template into an innovation contest design canvas. This was achieved in a re-design session involving the research team members. This step can either be considered a pivoting of the initial version of the template, or a second iteration of the design and development work on the template in phase 2. Next, the team improved the visual design of the canvas for enhanced commercial appeal, and created a complete visual user guide. Both the canvas and guide were subsequently uploaded to the web and disseminated during events. The drafting of the present paper represents another communication action, aimed at a more academic audience.

Fig. 2 shows the action research process. In the next section, we detail the results of the main steps in the process (marked with asterisks in the figure below).
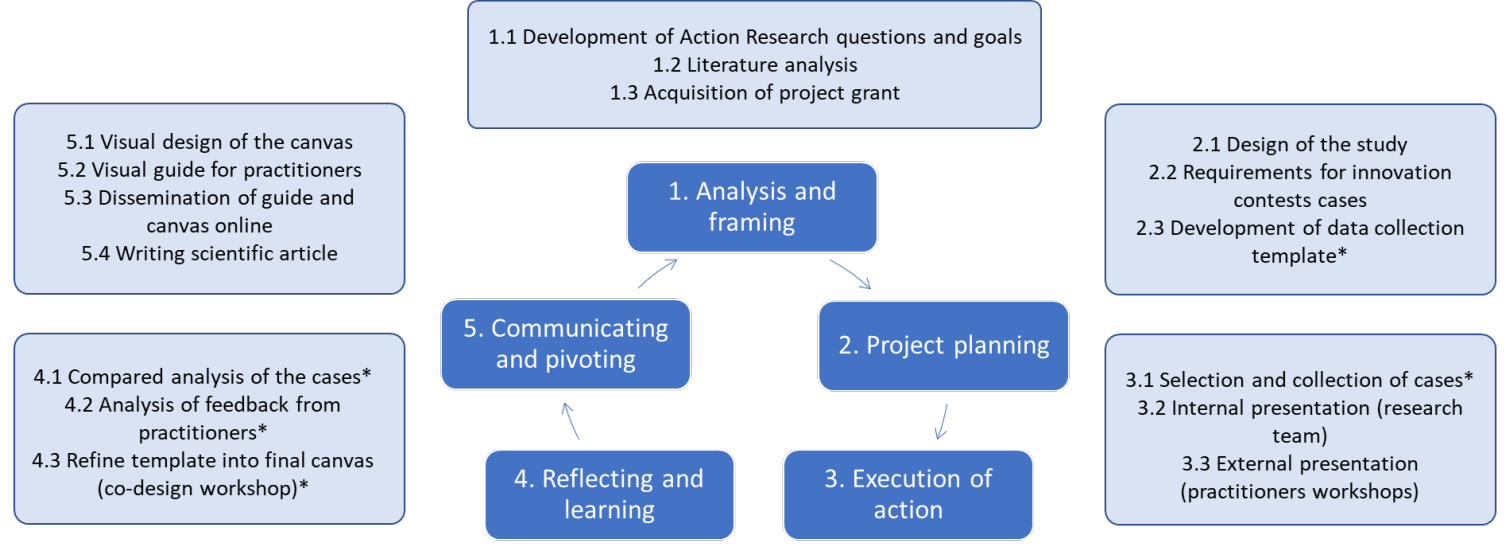

Fig. 2. The action research process followed in the study, according to the AIM-R model by (Guertler et al., 2020).

\section{Main steps in the action research process and results}

\subsection{Development of the data collection template}

The template to describe the cases consisted of a number of items that we assumed would collect appropriate information about the innovation contests under study. Items were chosen according to three selection drivers. First, we included the design elements or factors that comprise the backbone structure for all innovation prizes and contests, as referred to in all previous studies (Adamczyk et al., 2012; Bullinger \& Moeslein, 2010; Hjalmarsson \& Rudmark, 2012; Liotard \& Revest, 2018; Rodriguez Ferradas et al., 2017), as well as in booklets and guidebooks for innovation prizes and contest practitioners (Goldhammer et al., 2014; Nesta, 2014). Second, 
items were chosen in order to allow the template to account for aspects related to specific policy requirements and conditions that we had identified in SME innovation support literature. For example, we were interested in capturing the underlying organization model and governance of these contests (i.e. what partnerships the innovation agency needed to establish - if any - to activate the initiative); what the overall business model was (whether SMEs had to pay to take part in the contest); what kind of innovation outputs would the contest ultimately deliver to the SME seekers (ideas alone, or more tangible and developed outputs). We again sought to include items previously referred to in literature whenever possible. Third, since our main goal was practical, the template included items that made it possible to maintain a process-based perspective when describing contests (e.g. input, output, activities). As a general aim we tried to keep the template lean and practical to use (not including too many items).

The case description template was ultimately based on fourteen items. Table 2 provides a short description of each item and sets out the options we expected each item could capture in the example cases, along with references to overlapping or similar design elements in literature. It is worth noting that not all the items defined in the template can be directly identified and referenced in literature.

Table 2. The template used to describe the innovation contest example cases.

\begin{tabular}{|c|c|c|c|}
\hline ITEM & DESCRIPTION & $\begin{array}{l}\text { EXAMPLE } \\
\text { OPTIONS }\end{array}$ & $\begin{array}{l}\text { LITERATURE } \\
\text { REFERENCES }\end{array}$ \\
\hline $\begin{array}{l}\text { 1. Strategic } \\
\text { goal }\end{array}$ & $\begin{array}{l}\text { The overall strategic } \\
\text { reason for organizing } \\
\text { the contest }\end{array}$ & $\begin{array}{l}\text { Support SMEs in } \\
\text { adopting new } \\
\text { technologies; support } \\
\text { SMEs in developing or } \\
\text { improving new } \\
\text { products or processes }\end{array}$ & $\begin{array}{l}\text { Objectives (Murray et al., 2012); } \\
\text { Objectives and degree of } \\
\text { elaboration (Liotard \& Revest, } \\
\text { 2018); Replication (Adamczyk } \\
\text { et al., 2012) }\end{array}$ \\
\hline 2. Seeker & $\begin{array}{l}\text { Organization seeking } \\
\text { innovation (normally } \\
\text { the main beneficiary of } \\
\text { the contest) }\end{array}$ & $\begin{array}{l}\text { Public } \\
\text { administrations, } \\
\text { SMEs, startups }\end{array}$ & $\begin{array}{l}\text { Seeker (Chesbrough, 2010; } \\
\text { Lakhani, 2006; Terwiesch \& Xu, } \\
\text { 2008) }\end{array}$ \\
\hline 3. Input & $\begin{array}{l}\text { What the Seeker } \\
\text { brings to the contest } \\
\text { and object of the } \\
\text { Activities }\end{array}$ & $\begin{array}{l}\text { A product, a process, a } \\
\text { project, a business } \\
\text { case, a business model, } \\
\text { knowledge, data }\end{array}$ & \\
\hline $\begin{array}{l}4 . \\
\text { Challenge }\end{array}$ & $\begin{array}{l}\text { The problem or } \\
\text { opportunity that the } \\
\text { Seeker wishes to tackle } \\
\text { regarding the } \\
\text { presented Input }\end{array}$ & $\begin{array}{l}\text { Improving quality or } \\
\text { solving problems } \\
\text { regarding the input; } \\
\text { innovating the input; } \\
\text { applying new } \\
\text { technology }\end{array}$ & $\begin{array}{l}\text { Task/Topic specificity; Degree of } \\
\text { elaboration (Bullinger \& } \\
\text { Moeslein, 2010) }\end{array}$ \\
\hline 5. Output & $\begin{array}{l}\text { Applicable added value } \\
\text { that the Seeker } \\
\text { expects to source via } \\
\text { the contest }\end{array}$ & $\begin{array}{l}\text { Product ideas, } \\
\text { business ideas, } \\
\text { business models, } \\
\text { designs, prototypes, } \\
\text { technology, IP }\end{array}$ & \\
\hline
\end{tabular}




\begin{tabular}{|c|c|c|c|}
\hline ITEM & DESCRIPTION & $\begin{array}{l}\text { EXAMPLE } \\
\text { OPTIONS }\end{array}$ & $\begin{array}{l}\text { LITERATURE } \\
\text { REFERENCES }\end{array}$ \\
\hline 6. Solver & $\begin{array}{l}\text { Individuals or } \\
\text { organizations } \\
\text { executing the } \\
\text { Activities }\end{array}$ & $\begin{array}{l}\text { Students, startups, } \\
\text { SMEs, freelancers, } \\
\text { professionals, } \\
\text { researchers, scientists }\end{array}$ & $\begin{array}{l}\text { Solver (Lakhani, 2006; } \\
\text { Terwiesch \& Xu, 2008); Target } \\
\text { Group; Eligibility (Bullinger \& } \\
\text { Moeslein, 2010); Attraction } \\
\text { (Adamczyk et al., 2012); } \\
\text { Number of participants; } \\
\text { Difference in participant } \\
\text { backgrounds; Participant } \\
\text { self-selection; Degree of cultural } \\
\text { similarity among participants } \\
\text { (Isabel, Ferradas, Sandulli, } \\
\text { 2017) }\end{array}$ \\
\hline $\begin{array}{l}7 . \\
\text { Activities }\end{array}$ & $\begin{array}{l}\text { Actions capable of } \\
\text { delivering Outputs } \\
\text { from Inputs, including } \\
\text { problem-solving work, } \\
\text { specific methodologies, } \\
\text { and applying } \\
\text { know-how }\end{array}$ & $\begin{array}{l}\text { Coding (e.g. } \\
\text { hackathons), ideation } \\
\text { and design (e.g. } \\
\text { service design jams), } \\
\text { prototyping, } \\
\text { engineering }\end{array}$ & $\begin{array}{l}\text { Competition functioning } \\
\text { (Liotard \& Revest, 2018); } \\
\text { Facilitation (Adamczyk et al., } \\
\text { 2012); Community functionality } \\
\text { (Bullinger \& Moeslein, 2010) }\end{array}$ \\
\hline 8. Duration & $\begin{array}{l}\text { Duration of the } \\
\text { Activities and the } \\
\text { entire contest } \\
\text { (including preparatory } \\
\text { actions) }\end{array}$ & $\begin{array}{l}\text { One month, one week, } \\
\text { two days }\end{array}$ & $\begin{array}{l}\text { Duration (Liotard \& Revest, } \\
\text { 2018); Contest phase } \\
\text { (Adamczyk et al., 2012); } \\
\text { Contest period (Bullinger \& } \\
\text { Moeslein, 2010); Qualification } \\
\text { and staging (Murray et al., } \\
\text { 2012) }\end{array}$ \\
\hline $\begin{array}{l}9 . \\
\text { Resources }\end{array}$ & $\begin{array}{l}\text { Material or } \\
\text { non-material resources } \\
\text { instrumental to } \\
\text { executing the } \\
\text { Activities }\end{array}$ & $\begin{array}{l}\text { Software, technologies, } \\
\text { instruments, } \\
\text { laboratories, } \\
\text { infrastructures, user } \\
\text { panels }\end{array}$ & \\
\hline $\begin{array}{l}\text { 10. Legal } \\
\text { aspects }\end{array}$ & $\begin{array}{l}\text { How participants are } \\
\text { selected (e.g. via } \\
\text { public calls); how the } \\
\text { IPR (Intellectual } \\
\text { Property Rights) of } \\
\text { Outputs is managed }\end{array}$ & $\begin{array}{l}\text { IPR retained by } \\
\text { Solvers; IPR retained } \\
\text { by the Seeker; } \\
\text { IPR retailed by the } \\
\text { intermediary with } \\
\text { license options for } \\
\text { interested Seeker }\end{array}$ & $\begin{array}{l}\text { Participant eligibility; Rules and } \\
\text { guidelines for contest } \\
\text { organization; Intellectual } \\
\text { property clauses (Liotard \& } \\
\text { Revest, 2018) }\end{array}$ \\
\hline
\end{tabular}




\begin{tabular}{|c|c|c|c|}
\hline ITEM & DESCRIPTION & $\begin{array}{l}\text { EXAMPLE } \\
\text { OPTIONS }\end{array}$ & $\begin{array}{l}\text { LITERATURE } \\
\text { REFERENCES }\end{array}$ \\
\hline 11. Prizes & $\begin{array}{l}\text { Incentives provided to } \\
\text { the Solvers; } \\
\text { competition rules and } \\
\text { criteria for awarding } \\
\text { the incentives }\end{array}$ & $\begin{array}{l}\text { Monetary rewards, } \\
\text { career development }\end{array}$ & $\begin{array}{l}\text { Reward/motivation; Evaluation; } \\
\text { Rewards; Selection criteria for } \\
\text { the winning solution; Evaluating } \\
\text { the prize (Liotard \& Revest, } \\
\text { 2018); Ex ante incentive } \\
\text { specification; Ex ante technical } \\
\text { specification; Award } \\
\text { governance (Murray et al., 2012) }\end{array}$ \\
\hline $\begin{array}{l}12 . \\
\text { Business } \\
\text { model }\end{array}$ & $\begin{array}{l}\text { Costs and revenues } \\
\text { generated by the } \\
\text { contest }\end{array}$ & $\begin{array}{l}\text { Free for Seeker and } \\
\text { Solvers; access fee } \\
\text { required from Seeker } \\
\text { or Solvers; a mix of } \\
\text { the same }\end{array}$ & $\begin{array}{l}\text { Sponsorship (Adamczyk et al., } \\
2012 \text { ) }\end{array}$ \\
\hline 13. Results & $\begin{array}{l}\text { Overall outcomes that } \\
\text { the contest achieves } \\
\text { and its foreseen } \\
\text { impacts }\end{array}$ & $\begin{array}{l}\text { Enabling innovation } \\
\text { for the Seeker; } \\
\text { boosting know-how } \\
\text { among Solvers; } \\
\text { networking between } \\
\text { Solvers and Seeker } \\
\end{array}$ & $\begin{array}{l}\text { Prize performance (Murray et } \\
\text { al., 2012) }\end{array}$ \\
\hline $\begin{array}{l}14 . \\
\text { Governance }\end{array}$ & $\begin{array}{l}\text { How the contest is } \\
\text { managed and governed }\end{array}$ & $\begin{array}{l}\text { In-house by the } \\
\text { innovation agency; } \\
\text { within a partnership; } \\
\text { outsourced }\end{array}$ & $\begin{array}{l}\text { Organizer, Media (Bullinger \& } \\
\text { Moeslein, 2010) }\end{array}$ \\
\hline
\end{tabular}

\subsection{Selection and collection of the innovation contest example cases}

Example cases were selected from among innovation contests organized by public innovation intermediaries in three EU regions partnering the study: Trentino (IT), Oulu area (FI), and Tallinn area (EE). One of the ten cases actually pertained to the Helsinki area. The heterogeneity and variety of the collected data was ensured by the fact that the selected regions exhibit different innovation performance scores (respectively innovation leaders, moderate innovators, and strong innovators) (European Commission, 2019).

On the basis of the Analysis and framing of the study (Phase 1), the collected cases had to meet selection requirements regarding many structural elements: (i) beneficiaries (seekers): cases had to describe contests aimed at explicitly and primarily supporting SMEs (rather than LEs or startups); (ii) organizer: contests had to be organized by publicly-funded innovation intermediaries, meaning that we did not consider innovation contests organized by businesses of any kind (including SMEs); (iii) duration: contests had to deliver outputs in the short to medium term via a well-defined process, in order to more effectively support SMEs; (iv) outputs: we looked for innovation contests capable of delivering well developed, applicable, and easily implemented outputs (not simply ideas, but designs, prototypes, technologies); (v) scale: contests had to con- 
nect seekers with solvers on a regional scale, possibly involving face-to-face activities and events (therefore not via global or internet-based crowdsourcing platforms).

Once the cases had been selected, the research team proceeded to interview the managers of the targeted innovation contests to collect in-depth data, using the template as an outline for structured interviews. Each case description (completed template) comprised 4 to 6 pages of text. Table 3 lists short descriptions of the ten innovation contest example cases, the innovation agencies managing the contests, and the locations of the organizations. Full-page case descriptions were drafted later for the final guide for practitioners.

Table 3. Description of the innovation contests analyzed.

\begin{tabular}{|c|c|c|}
\hline $\begin{array}{l}\text { INNOVATION } \\
\text { CONTEST }\end{array}$ & SHORT DESCRIPTION & ORIGIN \\
\hline Agile Trialing & $\begin{array}{l}\text { An initiative allowing LEs and public } \\
\text { organizations to engage with technology } \\
\text { partners to test new consumer solution } \\
\text { prototypes in the owner deployment } \\
\text { environment }\end{array}$ & $\begin{array}{l}\text { BusinessOulu, Oulu, } \\
\text { Finland } \\
\text { (Applies the Agile Piloting } \\
\text { Programme of the Smart } \\
\text { Kalasatama, Helsinki) }\end{array}$ \\
\hline $\begin{array}{l}\text { BIC Open } \\
\text { Challenge }\end{array}$ & $\begin{array}{l}\text { A challenge to identify the best SME partner to } \\
\text { design and pursue a technology development } \\
\text { project starting from an unsatisfied need of one } \\
\text { LE }\end{array}$ & $\begin{array}{l}\text { Trentino Sviluppo, Trento, } \\
\text { Italy }\end{array}$ \\
\hline $\begin{array}{l}\text { Design } \\
\text { Bulldozer }\end{array}$ & $\begin{array}{l}\text { An initiative matching SMEs with designers } \\
\text { and marketing experts to increase company } \\
\text { product and brand management capabilities }\end{array}$ & $\begin{array}{l}\text { Estonian Design Centre, } \\
\text { Tallinn, Estonia }\end{array}$ \\
\hline Idea Sprint & $\begin{array}{l}\text { A rapid three-day initiative during which LEs } \\
\text { can source new product and business ideas, } \\
\text { including business plans, from SMEs and } \\
\text { startups }\end{array}$ & $\begin{array}{l}\text { BusinessOulu, Oulu, } \\
\text { Finland }\end{array}$ \\
\hline $\begin{array}{l}\text { Industrial } \\
\text { Problem Solving } \\
\text { with Physics } \\
\text { (IPSP) }\end{array}$ & $\begin{array}{l}\text { An annual one-week event involving physics } \\
\text { Ph.D. students for solving problems posed by } \\
\text { manufacturing companies }\end{array}$ & $\begin{array}{l}\text { University of Trento, } \\
\text { Trento, Italy }\end{array}$ \\
\hline $\begin{array}{l}\text { Product } \\
\text { Development } \\
\text { Project }\end{array}$ & $\begin{array}{l}\text { An eight-month initiative, integrated with } \\
\text { university courses involving design students, to } \\
\text { support companies during product development }\end{array}$ & $\begin{array}{l}\text { Aalto University, Helsinki, } \\
\text { Finland }\end{array}$ \\
\hline Proto Challenge & $\begin{array}{l}\text { A two-month initiative involving master } \\
\text { students for the re-engineering of mechanical } \\
\text { elements from manufacturing companies to } \\
\text { maximize benefits of additive manufacturing }\end{array}$ & $\begin{array}{l}\text { Hub Innovazione Trentino } \\
\text { (HIT), Trento, Italy }\end{array}$ \\
\hline $\begin{array}{l}\text { Smart Industry } \\
\text { Idea Hack }\end{array}$ & $\begin{array}{l}\text { A one-day event for manufacturing companies } \\
\text { to develop new digital service concepts together } \\
\text { with teams of young talents }\end{array}$ & $\begin{array}{l}\text { Tallinn Science Park } \\
\text { Tehnopol, Tallinn, Estonia }\end{array}$ \\
\hline
\end{tabular}




\begin{tabular}{lll}
\hline $\begin{array}{l}\text { INNOVATION } \\
\text { CONTEST }\end{array}$ & SHORT DESCRIPTION & ORIGIN \\
\hline SolutionJourney & $\begin{array}{l}\text { A two-month co-creation process in which new } \\
\text { product and business concepts are co-created } \\
\text { between LEs, SMEs, and users }\end{array}$ & $\begin{array}{l}\text { BusinessOulu, Oulu, } \\
\text { Finland }\end{array}$ \\
\hline UX Challenge & $\begin{array}{l}\text { A two-day Design Sprint initiative allowing } \\
\text { digital companies to test and improve the user } \\
\text { interfaces of digital products }\end{array}$ & $\begin{array}{l}\text { Hub Innovazione Trentino } \\
\text { (HIT), Trento, Italy }\end{array}$ \\
\hline
\end{tabular}

\subsection{Comparative analysis of the innovation contest cases}

In order to answer the research questions, the collected case descriptions were analyzed with a dual aim: first, verify whether the contests met the SME innovation support policy requirements set out in Section 2.1; second, we searched for recurring structural elements and design options across contests. Considering the practical goal of the study, the analysis also focused on the suitability of the applied template as a tool for effectively capturing the specificities of the selected cases.

A qualitative cross-case analysis was conducted to compare the ten examples (Eisenhardt, 1989; Halinen \& Törnroos, 2005). This analysis resulted in a table structured according to the data collection template, this time listing and counting all the recorded options that a given item (contest design element, for example solvers) presented across the ten collected cases: e.g. students (8), startups (3), freelancers (3), etc. The options were distilled from the qualitative data, clustering similar cases together, according to a Grounded Theory approach (Strauss \& Corbin, 1994). Given the exploratory scope of this study, the identification of options was not mutually exclusive, to allow peculiarities to emerge and avoid losing the complexity of each case. Similarly, each contest could present more than one option per item (e.g. solvers of a contest could be both students and startups), with the result that the total sum of options for a given item is often well above 10 .

In order to promote reliability, the initial analysis was conducted independently by the research team members. During this step, researchers developed second level qualitative data, including personal interpretations and annotations, regarding the data under analysis (first level data, or field data) (Van Maanen, 1979). Second level data are not arbitrary since they are developed by researchers sharing a common ground of interpretative concepts drawn from literature (Silverman, 2019). Incorporating second level data with field data enabled additional data triangulation to increase the reliability of the study (Denzin, 1973; Eisenhardt, 1989). The results of the individual analyses were shared, discussed, and consolidated during a team consensus meeting. The results are summarized in Table 4 and presented in full below. 
Table 4. Observed options in design items of ten innovation contests.

\begin{tabular}{|c|c|c|c|}
\hline ITEM & DESCRIPTION & DESIGN OPTIONS & $\mathbf{n}$ \\
\hline \multirow[t]{4}{*}{ 1. Strategic goal } & $\begin{array}{l}\text { The overall } \\
\text { strategic reason } \\
\text { for organizing the } \\
\text { contest }\end{array}$ & $\begin{array}{l}\text { Facilitating collaboration between companies, } \\
\text { students, professionals and raising awareness } \\
\text { of its benefits }\end{array}$ & 9 \\
\hline & & $\begin{array}{l}\text { Supporting SMEs in developing or improving } \\
\text { new products/services/processes }\end{array}$ & 8 \\
\hline & & $\begin{array}{l}\text { Support SMEs in adopting new technologies } \\
\text { and/or know-how }\end{array}$ & 5 \\
\hline & & $\begin{array}{l}\text { Supporting SMEs in creating new business } \\
\text { models }\end{array}$ & 4 \\
\hline \multirow[t]{3}{*}{ 2. Seeker } & $\begin{array}{l}\text { Organization } \\
\text { seeking innovation } \\
\text { (normally the } \\
\text { main beneficiary } \\
\text { of the contest) }\end{array}$ & Large companies & 8 \\
\hline & & SMEs & 6 \\
\hline & & Public organizations & 1 \\
\hline \multirow[t]{3}{*}{ 3. Input } & $\begin{array}{l}\text { What the Seeker } \\
\text { brings to the } \\
\text { contest and object } \\
\text { of the Activities }\end{array}$ & Challenge or problem description & 7 \\
\hline & & Products or services & 5 \\
\hline & & Process challenges & 1 \\
\hline \multirow[t]{2}{*}{ 4. Challenge } & $\begin{array}{l}\text { The problem or } \\
\text { opportunity that } \\
\text { the Seeker wishes } \\
\text { to tackle } \\
\text { regarding the } \\
\text { presented Input }\end{array}$ & Solving problems & 9 \\
\hline & & $\begin{array}{l}\text { Exploring / applying new } \\
\text { technologies/methodologies }\end{array}$ & 5 \\
\hline \multirow[t]{5}{*}{ 5. Output } & $\begin{array}{l}\text { Applicable added } \\
\text { value that the } \\
\text { Seeker expects to } \\
\text { source via the } \\
\text { contest }\end{array}$ & Designs & 6 \\
\hline & & Prototypes & 5 \\
\hline & & Business ideas & 3 \\
\hline & & Processes & 1 \\
\hline & & Technologies & 1 \\
\hline
\end{tabular}




\begin{tabular}{|c|c|c|c|}
\hline ITEM & DESCRIPTION & DESIGN OPTIONS & $\mathbf{n}$ \\
\hline \multirow[t]{5}{*}{ 6. Solver } & $\begin{array}{l}\text { Individuals or } \\
\text { organizations } \\
\text { executing the } \\
\text { Activities }\end{array}$ & Students or young graduates & 5 \\
\hline & & Startups & 5 \\
\hline & & SMEs & 4 \\
\hline & & Researchers & 1 \\
\hline & & Professionals & 1 \\
\hline \multirow[t]{7}{*}{ 7. Activities } & $\begin{array}{l}\text { Actions capable of } \\
\text { delivering } \\
\text { Outputs from } \\
\text { Inputs, including } \\
\text { problem-solving } \\
\text { work, specific } \\
\text { methodologies, } \\
\text { and know-how }\end{array}$ & Design & 8 \\
\hline & & Ideation & 7 \\
\hline & & Mentoring/sparring & 7 \\
\hline & & Team building & 6 \\
\hline & & Prototyping & 4 \\
\hline & & Testing with users & 2 \\
\hline & & Technology development & 1 \\
\hline \multirow[t]{7}{*}{ 8. Duration } & $\begin{array}{l}\text { Duration of the } \\
\text { Activities as well } \\
\text { as the whole } \\
\text { contest (including } \\
\text { preparatory } \\
\text { actions) }\end{array}$ & One day & 1 \\
\hline & & One month & 1 \\
\hline & & 2 months & 1 \\
\hline & & 4 months & 4 \\
\hline & & 6 months & 1 \\
\hline & & 10 months & 1 \\
\hline & & One year & 1 \\
\hline \multirow[t]{2}{*}{ 9. Resources } & $\begin{array}{l}\text { Material or } \\
\text { non-material } \\
\text { resources } \\
\text { instrumental to } \\
\text { executing the } \\
\text { Activities }\end{array}$ & Infrastructure & 6 \\
\hline & & People (Other than facilitator) & 5 \\
\hline
\end{tabular}




\begin{tabular}{|c|c|c|c|}
\hline ITEM & DESCRIPTION & DESIGN OPTIONS & $\mathbf{n}$ \\
\hline & & Software & 2 \\
\hline \multirow[t]{8}{*}{ 10. Legal aspects } & $\begin{array}{l}\text { How participants } \\
\text { are selected (e.g. } \\
\text { via public calls); } \\
\text { how the IPR } \\
\text { (Intellectual } \\
\text { Property Rights) } \\
\text { of Outputs are } \\
\text { managed }\end{array}$ & IPR to seekers & 5 \\
\hline & & IPR to solvers & 2 \\
\hline & & IPR options for interested parties & 2 \\
\hline & & Free exploration & 1 \\
\hline & & Public selection of solvers & 9 \\
\hline & & Seekers selected by organizer & 5 \\
\hline & & Public selection of seekers & 4 \\
\hline & & No selection & 1 \\
\hline \multirow[t]{5}{*}{ 11. Prizes } & $\begin{array}{l}\text { Incentives } \\
\text { provided to the } \\
\text { Solvers; } \\
\text { competition rules } \\
\text { and criteria for } \\
\text { awarding the } \\
\text { incentives }\end{array}$ & Monetary rewards & 4 \\
\hline & & Business opportunities & 4 \\
\hline & & Career development & 4 \\
\hline & & Learning opportunities & 3 \\
\hline & & Academic credits & 1 \\
\hline \multirow[t]{2}{*}{$\begin{array}{l}\text { 12. Business } \\
\text { model }\end{array}$} & $\begin{array}{l}\text { Costs and } \\
\text { revenues } \\
\text { generated by the } \\
\text { contest }\end{array}$ & Free & 5 \\
\hline & & Access fees & 5 \\
\hline \multirow[t]{4}{*}{ 13. Result } & $\begin{array}{l}\text { Overall outcomes } \\
\text { that the contest } \\
\text { achieves and its } \\
\text { foreseen impacts }\end{array}$ & New/improved designs & 5 \\
\hline & & New/improved prototypes & 4 \\
\hline & & New business idea/opportunities & 3 \\
\hline & & New technology & 1 \\
\hline 14. Governance & $\begin{array}{l}\text { How the contest is } \\
\text { managed and } \\
\text { governed }\end{array}$ & Conducted within a partnership & 8 \\
\hline
\end{tabular}

ISSN 2183-0606 


\begin{tabular}{llll}
\hline ITEM & DESCRIPTION & DESIGN OPTIONS & $\mathbf{n}$ \\
\hline & In-house by the innovation agency & 2 \\
\hline
\end{tabular}

The main strategic goal of the innovation contests analyzed was to facilitate collaboration between companies, students, professionals, and raise awareness of the benefits of open innovation (9 out of 10). Another primary motivation for the contests was to support SMEs in developing or improving new products, services, and processes (8). Other aims, like supporting SMEs in adopting new technologies and/or know-how (5), and creating new business models (4) were also mentioned. Seekers were either large companies (8) or SMEs (6). The public organization was the seeker in one innovation contest. Input to the open innovation processes was typically a description of an NPD issue (7), a product/service (5) to be improved, or process-related challenges (1). Regarding the Challenge, seekers tried to solve a problem (9), or explore/apply new technologies/methodologies (5). As Output, seekers received designs (6), prototypes (5), new business ideas (3), processes (1), and technologies (1). Solvers were mainly university students (5), startups (5), and SMEs (4) but researchers (1), and professionals (1) were also included. Notably, in 4 cases out of 10 when SMEs were acting as solvers rather than seekers (who were LEs or public companies), the task they received was to pursue outbound Open Innovation. For example, in the SolutionJourney contest, when SMEs competed to develop and implement a future airport solution at the local airport facilities.

The Activities conducted by solvers to tackle Challenge mainly entailed design (8), ideation (7), mentoring (7), team building (6), and prototyping (4). User testing and technology development was also performed. The Duration of contests varied from one day to one year. The most common was four months, including preparation time (4). The Resources needed included infrastructures (6), experts (5), and software (2), to execute the innovation contest. As regards the Legal aspects, IPR output policy depended on the characteristics of the innovation contest.

The Prizes, or incentives for solvers, varied from monetary rewards (4) to non-tangible benefits, such as career development (4), business opportunities (4), learning opportunities (3), and academic credits (1). For example, the UX Challenge contest offered a small non-monetary reward to the winning team; however, it leveraged the intrinsic motivations of solvers such as professional learning experiences, connections with companies, and media visibility. The analyzed contests delivered the prospected Outputs by means of Activities that included team building (6), ideation (7), design (8), prototyping (4), testing with users (2), mentoring/sparring (7), and technology development (1). Results were often tangible, like new or improved designs (5), new/improved prototypes (4), new business ideas/opportunities (3), and even new technology (1). The Business models of the contests were closely balanced between those applying access fees for seekers (5), and those in which all costs were covered by the organizing innovation agency (5). Finally, as regards Governance, most of the contests were conducted in partnerships (8), with the organizing innovation agency collaborating with other local partners, such as universities, research centers, industry representation associations, or even the Seekers themselves. For example, the Agile Trialing contest, in which SMEs acted as Solvers testing solutions for the Seeker in a real test environment, was managed and facilitated in collaboration between the innovation agency and the LE owning the test environment (Seeker). Conversely, only two out of the ten innovation contests were executed in-house by the innovation agency alone. 
Overall, these findings provided evidence that innovation contests are valid instruments to help break down barriers to promoting OI in SMEs (see Sec. 5). In addition, some flaws and room for improvement in the template were diagnosed.

\subsection{Analysis of feedback from practitioners}

The ten example cases were then presented to practitioners from institutions involved in supporting innovation in SMEs (innovation agencies, development authorities, technology transfer offices, company representation organizations) during three one-day workshops organized in the three countries involved. The data generated from this initiative was mainly intended to support the practical purpose of the action research: evaluating the viability of the template used as a blueprint for an innovation contest design canvas.

The three workshops took place between October 2018 and February 2019 with a total of 48 participants (average participants per workshop $=16$ ). The workshops were intended to act as informal hands-on sessions for the presentation of the example cases and template, while generating feedback and questions from participants. Feedback was elicited during short question \& answer sessions (about 10 minutes) following presentation of each case study. The research team recorded feedback from participants (first level data), and developed interpretations and field notes of interaction among participants (second level data). All data were independently analyzed and clustered by the researchers, consolidated in a consensus meeting, and then triangulated with the other data in order to inform the next phases of the study.

In summary, two major observations were distilled from the workshops. 1) The vast majority of participants posing questions and making comments demonstrated an understanding of the main design elements of an innovation contest (e.g. Seeker, Solver, Challenge); conversely, other template items proved to be less well understood (e.g. Input, or Legal aspects). We concluded that the template could be simplified and that each item should come with a short but clear description in order to be more self-explanatory. 2) Many questions from the audience were practical and regarded the managerial aspects of setting up and running a contest (e.g. the necessary partnerships, the regulations and legal work, the right incentives for solvers); we concluded that the canvas should assign adequate space for "how-to" items.

\subsection{Refining the template into the final design canvas}

Following on from the findings of the two analyses mentioned above, a one-day re-design session was held among the research team members to review the template and render it more complete, consistent, unambiguous, and adequate as a blueprint for the final canvas. Some items were merged, divided, eliminated, or renamed: this was done for case items that: (i) did not collect consistent (comparable) data across the ten cases; (ii) collected data that overlapped with other items; (iii) did not collect enough useful information; (iv) was only partially intelligible to practitioners. The results of the re-design session are described below.

The initial version of the template included fourteen items, while the reviewed version (which is structurally equivalent to the final canvas) has twelve items. The items that essentially did 
not change between the two versions are: Strategic goal (which was just renamed Goal, for the sake of simplicity), Seeker, Challenge, Solver, Activities, Business model, and Governance. In the canvas Input was eliminated because its contents and interpretation often overlapped with those of Challenge. Duration was renamed because its contents and interpretation involved two different objects: on one hand the time required for activities like team building, ideation, design, prototyping, user testing, mentoring/sparring, and technology development; on the other hand, the total time necessary for the innovation agency to set up and execute the contest. For this reason, in the final canvas Duration was replaced with Timeline, which regards the timing, stages, milestones, and events needed to both organize and conduct the whole initiative. Resources was removed, because it was too detailed to be included in a high-level framework, and can probably be deduced from Activities. In the template, Legal aspects involved many different aspects including IPR regulations, and participant selection and rules, both very important areas from a contest design perspective. Consequently, it was divided into two items, IPRand Regulations, with the former covering the IPR policy for solutions, and the latter regarding the rules regulating the participation of all parties. Prize was renamed Incentives, considering the many non-monetary reasons that motivate solvers to participate. Finally, Outputs and Results, which addressed much the same information, were merged into a newly designed item called Solutions. The re-design results are summarized in Table 5.

Table 5. Review of the data collection template towards the final design canvas.

\begin{tabular}{|c|c|c|c|}
\hline \multicolumn{2}{|c|}{ DATA COLLECTION TEMPLATE } & \multicolumn{2}{|c|}{ DESIGN CANVAS } \\
\hline ITEM & DESCRIPTION & ITEM & DESCRIPTION \\
\hline 1. Strategic goal & $\begin{array}{l}\text { The overall strategic reason } \\
\text { for organizing the contest }\end{array}$ & 1. Goal & $\begin{array}{l}\text { The overall strategic reason } \\
\text { why the contest is } \\
\text { organized by the } \\
\text { intermediary innovation } \\
\text { agency }\end{array}$ \\
\hline 2. Seeker & $\begin{array}{l}\text { Organization seeking } \\
\text { innovation (normally the } \\
\text { main beneficiary of the } \\
\text { contest) }\end{array}$ & 2. Seekers & (unchanged) \\
\hline 3. Input & $\begin{array}{l}\text { What the Seeker brings to } \\
\text { the contest and object of } \\
\text { the Activities }\end{array}$ & & \\
\hline 4. Challenge & $\begin{array}{l}\text { The problem or } \\
\text { opportunity that the Seeker } \\
\text { wishes to tackle regarding } \\
\text { the presented Input }\end{array}$ & 3. Challenge & $\begin{array}{l}\text { The problem or } \\
\text { opportunity that the Seeker } \\
\text { wishes to tackle regarding a } \\
\text { product, process, } \\
\text { technology, or business }\end{array}$ \\
\hline 5. Output & $\begin{array}{l}\text { Applicable added value } \\
\text { that the Seeker expects to } \\
\text { source via the contest }\end{array}$ & & \\
\hline
\end{tabular}




\begin{tabular}{|c|c|c|c|}
\hline \multicolumn{2}{|c|}{ DATA COLLECTION TEMPLATE } & \multicolumn{2}{|c|}{ DESIGN CANVAS } \\
\hline ITEM & DESCRIPTION & ITEM & DESCRIPTION \\
\hline 6. Solver & $\begin{array}{l}\text { Individuals or organizations } \\
\text { executing the Activities }\end{array}$ & 4. Solvers & (unchanged) \\
\hline 7. Activities & $\begin{array}{l}\text { Actions capable of } \\
\text { delivering Outputs from } \\
\text { Inputs, including } \\
\text { problem-solving work, } \\
\text { specific methodologies, and } \\
\text { know-how }\end{array}$ & 5. Activities & $\begin{array}{l}\text { Actions capable of } \\
\text { delivering Solutions by } \\
\text { means of problem-solving } \\
\text { work, specific } \\
\text { methodologies, and } \\
\text { know-how }\end{array}$ \\
\hline 8. Duration & $\begin{array}{l}\text { Duration of the Activities, } \\
\text { as well as the whole contest } \\
\text { (including preparatory } \\
\text { actions) }\end{array}$ & 6. Timeline & $\begin{array}{l}\text { The duration, milestones, } \\
\text { stages, and events required } \\
\text { to set up and carry out the } \\
\text { entire contest }\end{array}$ \\
\hline 9. Resources & $\begin{array}{l}\text { Material or non-material } \\
\text { resources instrumental to } \\
\text { executing the Activities }\end{array}$ & & \\
\hline \multirow[t]{2}{*}{ 10. Legal aspects } & $\begin{array}{l}\text { How participants are } \\
\text { selected (e.g. via public } \\
\text { calls); how the IPR } \\
\text { (Intellectual Property } \\
\text { Rights) of Outputs are } \\
\text { managed }\end{array}$ & 7. IPR & $\begin{array}{l}\text { Intellectual Property } \\
\text { Rights (IPR) policy for } \\
\text { Solutions }\end{array}$ \\
\hline & & 8. Regulations & $\begin{array}{l}\text { The formal and legal } \\
\text { framework regulating all } \\
\text { aspects of the contest }\end{array}$ \\
\hline 11. Prizes & $\begin{array}{l}\text { Incentives provided to the } \\
\text { Solvers; competition rules } \\
\text { and criteria for awarding } \\
\text { the incentives }\end{array}$ & 9. Incentives & $\begin{array}{l}\text { The motivational elements } \\
\text { for Solvers and/or Seekers, } \\
\text { including prizes }\end{array}$ \\
\hline $\begin{array}{l}\text { 12. Business } \\
\text { model }\end{array}$ & $\begin{array}{l}\text { Costs and revenues } \\
\text { generated by the contest }\end{array}$ & $\begin{array}{l}\text { 10. Business } \\
\text { model }\end{array}$ & (unchanged) \\
\hline 13 Result & $\begin{array}{l}\text { Overall outcomes that the } \\
\text { contest achieves and its } \\
\text { foreseen impacts }\end{array}$ & 11. Solutions & (unchanged) \\
\hline 14. Governance & $\begin{array}{l}\text { How the contest is } \\
\text { managed and governed }\end{array}$ & 12. Governance & (unchanged) \\
\hline
\end{tabular}

Keeping in mind the workshop findings, the twelve resulting items were grouped into coherent categories, to facilitate users when approaching the canvas.Three groups were identified, and given titles: Why group, including all the strategic elements that determine the added value of an innovation contest (Goal, Seekers, Challenge, Solutions); Whatgroup, including the items that contribute to bringing about the added value (Activities, Solvers, Incentives, Timeline); 
How group, including the items regarding managerial aspects of running a contest (Governance, Business model, IPR, Regulation). Next, short explanatory descriptions and graphic icons were added to all canvas items for increased immediacy. The final canvas (shown in Figure 3) was named "Innovation Challenge Design Canvas": we opted for the term "challenge" rather than "contest" because, while the former is less common in innovation prize literature, it appears to be more widely used by practitioners.

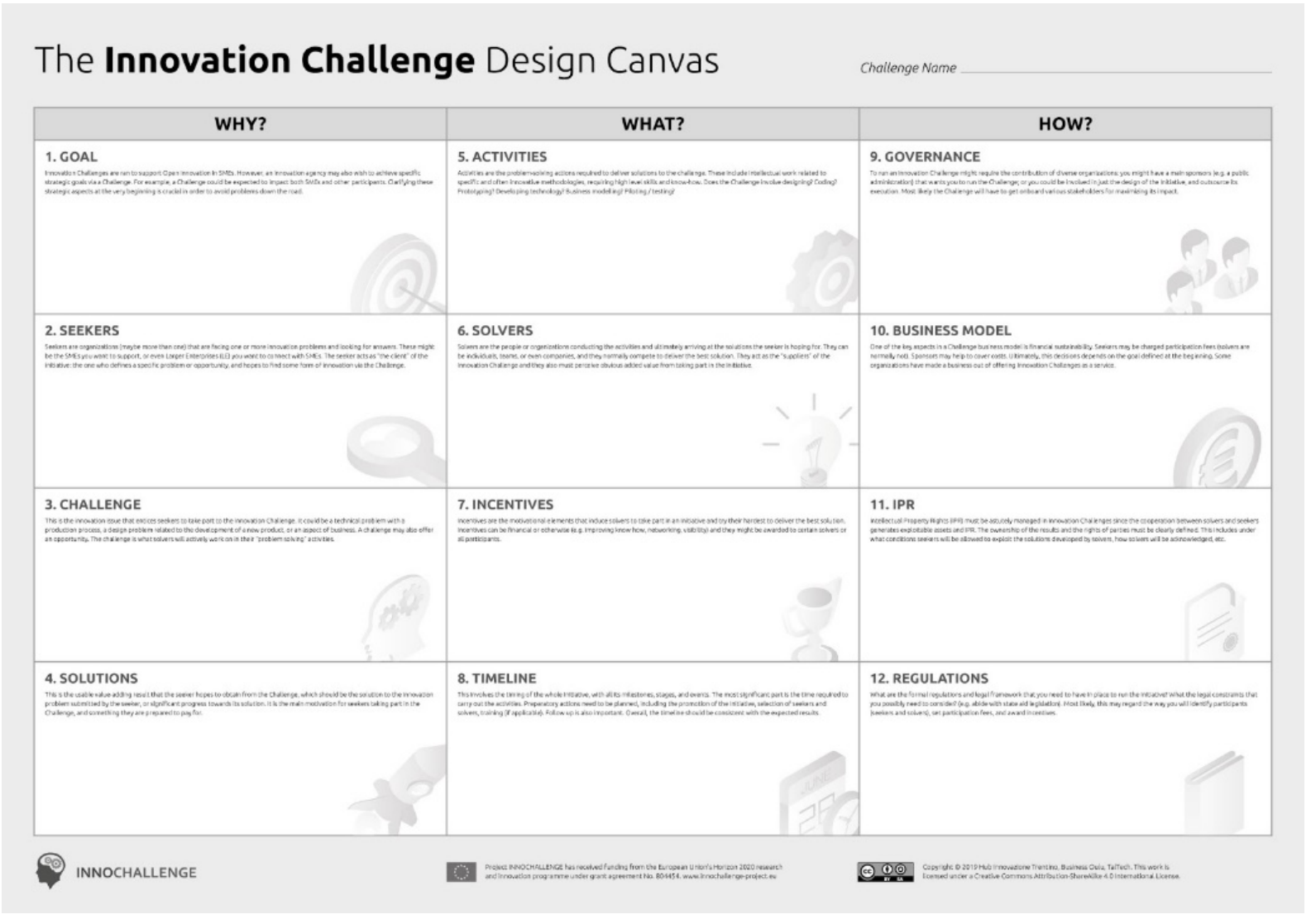

Figure 3. The final Innovation Challenge Design Canvas.

\section{Discussion}

The findings from our action research suggest that public innovation intermediaries can effectively adopt innovation contests to support SMEs in pursuing Open Innovation (Chesbrough, 2003, 2010; Chesbrough \& Kardon Crowther, 2006; Piller \& Walcher, 2006; West \& Bogers, 2014).

As regards the first research question (Whether innovation contests can help break down the barriers that SMEs face in pursuing OI), the contest cases appear to satisfy the policy requirements for effectively supporting SMEs to overcome these barriers. Firstly, the relatively short time horizons of the analyzed contests (within 6 months, in eight cases out of ten) is in line with the EC 
recommendation to "think small first" when designing new innovation support programs for SMEs (European Commission, 2008, 2009b, 2018a). Secondly, the marked involvement of university students, as solvers, researchers, and mentors (observed in six cases out of ten) likely increases proximity between companies and higher education systems (Chesbrough \& Vanhaverbeke, 2018; Oliveira et al., 2017). Thirdly, by establishing successful new connections between seekers and solvers from different industries and value chains (in both the private and public sectors), contests help shift the support focus from single firms to the Regional Innovation Ecosystems (RIE) (Chesbrough \& Vanhaverbeke, 2018; Cooke, 2001; Tödtling \& Trippl, 2005). Fourthly, the observed leading role of public innovation agencies in organizing and managing these initiatives within partnerships (observed in eight cases out of ten), means that contests can strengthen the role of innovation agencies as OI intermediaries within the RIE (Katzy et al., 2013; Lee et al., 2010; Oliveira et al., 2017).

These initial observations, though based on an explorative and qualitative study, carry significant implications for policymakers, at the regional, national, and European levels. Innovation agencies and development authorities whose missions include supporting innovation in SMEs should include innovation contests in their toolkits to support Open Innovation in SMEs (together with traditional policy instruments such as grants, vouchers, technology transfer programs, and so forth). They should also undertake experimentation within their contest policies, as recommended by the European Commission (European Commission, 2009a, 2018b). Furthermore, governing authorities should consider launching and facilitating capacity building programs (like the above-mentioned H2020 INNOSUP-05 and INNOSUP-06 Coordination and Support Actions) aimed at further validating and mainstreaming innovation contests as effective, feasible, and scalable SME OI policy instruments.

As regards the second research question (How innovation contests should be designed and structured to meet this goal), our findings show that the analyzed innovation contests feature a number of design elements (including Governance, Business model, Regulations) that were often neglected, or at least not directly mentioned (see Table 2), in existing theoretical frameworks for innovation prizes and contests (Adamczyk et al., 2012; Bullinger \& Moeslein, 2010; Hjalmarsson \& Rudmark, 2012; Liotard \& Revest, 2018; Murray et al., 2012; Rodriguez Ferradas et al., 2017). However, these design elements, once utilized to describe the current state of practice (during the initial description of the case studies, and in workshop discussions) were seen to delineate major managerial issues that practitioners address when designing innovation contests. On the strength of this, we propose a novel framework consisting of twelve design elements that were seen to embrace the peculiarities of the structural and design options implemented in the innovation contests object of this study. We consider this framework to be robust for two reasons. Firstly, it is strongly founded on the state-of-art innovation prize and contest design frameworks presented in detail in Section 2. Secondly, it is the result of a process of field-testing and optimization based on 10 real-life applications, together with further evaluation by 48 potential users (innovation management practitioners).

The action research methodology we implemented (Baskerville \& Wood-Harper, 1996;1998; Checkland \& Holwell, 1998; Guertler et al., 2020; Lewin, 1946; Peffers et al., 2007) enabled us to propose the newly adapted framework as a practical contest design canvas for practitioners. This has major implications for innovation management practitioners, since the canvas can help 
bridge the gap between theory and practice when designing Open Innovation contests, for the following reasons. The frameworks already available in literature included a rather large number of elements (20, or 15), while the proposed canvas includes only 12 , which considerably simplifies its comprehension. As already mentioned, previous frameworks failed to capture certain design elements relevant to practitioners and required in order to understand how to design an innovation contest. Finally, previous frameworks did not come in the form of a usable (and freely downloadable) visual tool, including explanatory descriptions of each design element along with a user guide. At the time of writing of this paper, both the canvas and user guide have been downloaded by more than 400 practitioners $^{2}$.

\section{Conclusions and further research}

This study contributes to existing research into the structure and operation of innovation prizes and contests as instruments to support Open Innovation in businesses. The paper focuses specifically on innovation contests organized by innovation agencies with the aim of supporting OI processes in SMEs.

An action research methodology was applied, based on analysis of a consistent number of innovation contest examples. This allowed theoretical advancements to be pursued, as well as identifying practical issues for practitioners. In the theoretical aspect, we collected qualitative evidence on how contests can be adopted by innovation agencies to break down the barriers normally faced by SMEs when engaging in Open Innovation. Most existing literature discusses innovation contests and prizes as instruments adopted mainly by Large Enterprises (Chesbrough, 2003, 2010; Chesbrough \& Kardon Crowther, 2006; Piller \& Walcher, 2006; West \& Bogers, 2014). The study also contributes to existing theoretical discussion on the structural elements of innovation prizes and contests, by pointing out the importance of certain design dimensions not directly addressed in literature (Adamczyk et al., 2012; Bullinger \& Moeslein, 2010; Hjalmarsson \& Rudmark, 2012; Rodriguez Ferradas et al., 2017). This suggests that the innovation contests we investigated were somewhat different from those analyzed in previous research, consequently requiring adequate further qualitative investigation in future research. Finally, as discussed in the previous section, our action research resulted in the delivery of a practical tool (design canvas) usable by practitioners.

However, this study represents an exploratory contribution to the topic and we acknowledge that it suffers from a number of limitations, which at the same time could pave the way for further research. We are aware that ten cases are not an adequate sample in order to generalize the cited theoretical findings. Further research should seek, through quantitative and qualitative study, to stress test and validate the current 12 item based framework (canvas) with more cases (e.g. representing more EU countries, or with different time horizons) to verify whether our findings still hold true. We are aware that a 12 item framework is an approximation and simplification of a potentially more complex model. Further research, possibly based on large data sets and advanced statistical analyses, could prove that a framework based on more, or less items, is more appropriate. In addition to such enhanced modeling, further research should

$2 \quad$ The canvas and visual user guide are freely downloadable at www.innochallenge-project.eu. 
also seek to identify distinctive and coherent profiles or types of innovation contests for SMEs, as was recently achieved for startup accelerators (Pauwels et al., 2016), and startup engagement programs in Large Enterprises (Weiblen \& Chesbrough, 2015). The selection criteria for sample cases could be improved in future studies: for example, selecting only contests that proved (based on reliable parameters) to positively impact the OI capacity of SMEs, something we were unable to establish. Considering the practical outcomes of our study, further research should seek to validate the proposed canvas as a usable and effective tool for practitioners when designing new innovation contests. Finally, in light of the policy-level implications we discussed, further research should evaluate the feasibility, scalability, cost-effectiveness, and consequent sustainability of innovation contests across countries, industries, and different types of innovation agencies. Research could also identify limits for the policy instrument, the most effective application domains (e.g. particular industries; certain types of challenge), and domain-related design options.

\section{Acknowledgements}

This study was funded by the Horizon 2020 research and innovation Work Programme of the European Commission, under the call for proposal INNOSUP-05 2018-2020, managed by EASME - the Executive Agency for Small and Medium Enterprises of the EC. We would like to thank EASME for funding the project, and supporting the dissemination of its results.

\section{References}

Adamczyk, S., Bullinger, A. C., \& Möslein, K. M. (2012). Innovation Contests: A Review, Classification and Outlook. Creativity and Innovation Management, 21(4), 335-360.

Armisen, A., Sánchez-Hernández, G., \& Majchrzak, A. (2015). Consensus in innovation contest categorisation by means of fuzzy partitions. Applied Soft Computing Journal, 35, 921-930.

Baskerville, R. L., \& Wood-Harper, A. T. (1996). A critical perspective on action research as a method for information systems research. Journal of Information Technology, 11(1996), 235-246.

Baskerville, R. L., \& Wood-Harper, A. T. (1998). Diversity in information systems action research methods. European Journal of Information Systems, 7(2), 90-107.

Bockstedt, J., Druehl, C., \& Mishra, A. (2015). Problem-solving effort and success in innovation contests: The role of national wealth and national culture. Journal of Operations Management, 36 (March 2018), 187-200.

Boudreau, K. J., Lacetera, N., \& Lakhani, K. R. (2011). Incentives and problem uncertainty in innovation contests: An empirical analysis. Management Science, 57(5), 843-863.

Briscoe, G., \& Mulligan, C. (2014). Digital Innovation: The Hackathon Phenomenon. Creativeworks London, 6, 1-13.

Brunswicker, S., \& Vanhaverbeke, W. (2015). Open Innovation in Small and Medium-Sized 
Enterprises (SMEs): External Knowledge Sourcing Strategies and Internal Organizational Facilitators. Journal of Small Business Management, 53(4), 1241-1263.

Bullinger, A. C., \& Moeslein, K. (2010). Innovation contests - where are we? 16th Americas Conference on Information Systems 2010, AMCIS 2010, 2, 795-803.

Bullinger, A. C., Neyer, A. K., Rass, M., \& Moeslein, K. M. (2010). Community-based innovation contests: Where competition meets cooperation. Creativity and Innovation Management, 19(3), 290-303.

Burstein, M. J., \& Murray, F. E. (2016). Innovation Prizes in Practice and Theory. Harvard Journal of Law 83 Technology, 29(2).

Checkland, P., \& Holwell, S. (1998). Action Research: Its Nature and Validity. Systemic Practice and Action Research, 11(1), 9-21.

Chesbrough, H. W. (2003). Open Innovation: The New Imperative for Creating and Profiting from Technology. Harvard Business School Press.

Chesbrough, H. W. (2009). Open R\&D and open innovation: Exploring the phenomenon. $R$ and D Management, 39(4), 311-316.

Chesbrough, H. W. (2010). The future of open innovation. RED Management, 40(3), 213-221.

Chesbrough, H. W. (2014). Open innovation: The next decade. Research Policy, 43(5), 805-811.

Chesbrough, H. W., \& Kardon Crowther, A. (2006). Beyond high tech: early adopters of open innovation in other industries. REDD Management, 36.

Chesbrough, H. W., \& Vanhaverbeke, W. (2018). Open innovation and Public Policy in the EU with Implications for SMEs. W. Vanhaverbeke, F. Frattini, N. Roijakkers, Es M. Usman (Eds.), Researching Open Innovation in SMEs, 455-492.

Chiaroni, D., Chiesa, V., \& Frattini, F. (2011). The Open Innovation Journey: How firms dynamically implement the emerging innovation management paradigm. Technovation, 31(1), $34-43$.

Cohen, W. M., \& Levinthal, D. A. (2000). Absorptive Capacity: A New Perspective on Learning and Innovation. Strategic Learning in a Knowledge Economy, 39-67.

Cooke, P. (2001). Regional Innovation Systems, Clusters, and the Knowledge Economy. Industrial and Corporate Change, 10(4), 945-974.

Denzin, N. K. (1973). The research act (3rd ed.). Aldine.

Eisenhardt, K. M. (1989). Building Theories from Case Study Research. Academy of Management Review, 14(4), 532-550.

European Commission. (2008). A "Small Business Act" for Europe. COM(2008) 394 final.

European Commission. (2009a). Making Public Support for Innovation in the EU More Effective: Lessons Learned from a Public Consultation for Action at Community Level (COMMISSION STAFF WORKING DOCUMENT, Issue September). 
European Commission. (2009b). Report of the Expert Group Think Small First - Considering SME interests in policy-making including the application of an 'SME Test' (Issue March).

European Commission. (2018a). Annual Report on European SMEs The 10th anniversary of the Small Business Act.

European Commission. (2018b). Horizon 2020 Work Programme 2018-2020. Innovation in small and medium-sized enterprises (Issue July 2019).

European Commission. (2019). European Innovation Scoreboard 2019.

Gassmann, O., \& Enkel, E. (2004). Towards a Theory of Open Innovation: Three Core Process Archetypes. RED Management Conference (RADMA), 16(3), 89-101.

Gök, A. (2016). The impact of innovation inducement prizes. In Handbook of Innovation Policy Impact (Issue 13, pp. 649-675).

Goldhammer, J., Mitchell, K., Parker, A. "Nes," Anderson, B., \& Joshi, S. (2014). The craft of incentive prize design: Lessons from the public sector.

Greco, M., Grimaldi, M., \& Cricelli, L. (2017). Hitting the nail on the head: Exploring the relationship between public subsidies and open innovation efficiency. Technological Forecasting and Social Change, 118, 213-225.

Gregor, S., \& Hevner, A. R. (2013). Positioning and Presenting Design Science Types of Knowledge in Design Science Research. MIS Quarterly, 37(2), 337-355.

Guertler, M. R., Kriz, A., \& Sick, N. (2020). Encouraging and enabling action research in innovation management. $R$ and D Management, 50(3), 380-395.

Guertler, M. R., Sick, N., \& Kriz, A. (2019). A Discipline-Spanning Overview of Action Research and Its Implications for Technology and Innovation Management. Technology Innovation Management Review, 9(4), 48-65.

Halinen, A., \& Törnroos, J. Å. (2005). Using case methods in the study of contemporary business networks. Journal of Business Research, 58(9 SPEC. ISS.), 1285-1297.

Hjalmarsson, A., \& Rudmark, D. (2012). Designing Digital Innovation Contests. International Conference on Design Science Research in Information Systems, 7286(2012).

Jönsson, S. (1991). Action Research. In H.-E. Nissen, H. K. Klein, \& R. Hirschheim (Eds.), Information systems research: contemporary approaches and emergent traditions (pp. 371-396). Elsevier North-Holland, Inc.

Kalil, T. (2006). Prizes for Technological Innovation. Working Paper, December, 1-34.

Kathan, W., Matzler, K., Füller, J., Hautz, J., \& Hutter, K. (2014). Open innovation in SMEs: A case study of a regional open innovation platform. Problems and Perspectives in Management, 12(1), 161-171.

Katzy, B., Turgut, E., Holzmann, T., \& Sailer, K. (2013). Innovation intermediaries: a process view on open innovation coordination. Technology Analysis 85 Strategic Management, 25(3), $295-309$. 
Kay, L. (2012). Opportunities and Challenges in the Use of Innovation Prizes as a Government Policy Instrument. Minerva, 50(2), 191-196.

King, A. A., \& Lakhani, K. R. (2011). The Contingent Effect of Absorptive Capacity: An Open Innovation Analysis. In Harvard Business School.

Kokshagina, O., Gillier, T., Cogez, P., Le Masson, P., \& Weil, B. (2017). Using innovation contests to promote the development of generic technologies. Technological Forecasting and Social Change, 114, 152-164.

Kuechler, B., \& Vaishnavi, V. (2008). Theory Development in Design Science Research: Anatomy of a Research Project. Proceedings of the Third International Conference on Design Science Research in Information Systems and Technology.

Lakhani, K. R. (2006). Broadcast search in problem solving: Attracting solutions from the periphery. Portland International Conference on Management of Engineering and Technology, $6(\mathrm{c}), 2450-2468$.

Lee, S., Park, G., Yoon, B., \& Park, J. (2010). Open innovation in SMEs-An intermediated network model. Research Policy, 39(2), 290-300.

Lewin, K. (1946). Action Research and Minority Problems. Journal of Social Issues, 2, 34-46.

Liotard, I., \& Revest, V. (2018). Contests as innovation policy instruments: Lessons from the US federal agencies' experience. Technological Forecasting and Social Change, 127(March 2016), $57-69$

Mack, T., \& Landau, C. (2015). Winners, losers, and deniers: Self-selection in crowd innovation contests and the roles of motivation, creativity, and skills. Journal of Engineering and Technology Management - JET-M, 37, 52-64.

Mäkelä, A. (2017). Fostering innovation and growth in the digital age: the case for challenge prizes in Europe. 32(December), 11-15.

Makkonen, T., \& Inkinen, T. (2014). Innovation quality in knowledge cities: Empirical evidence of innovation award competitions in Finland. Expert Systems with Applications, 41(12), $5597-5604$.

Masters, W. a., \& Delbecq, B. (2008). Accelerating Innovation with Prize Rewards: History and Typology of Technology Prizes and a New Contest Design for Innovation in African Agriculture. International Food Policy Research Institute, December, 1-44.

Murray, F., Stern, S., Campbell, G., \& MacCormack, A. (2012). Grand Innovation Prizes: A theoretical, normative, and empirical evaluation. Research Policy, 41(10), 1779-1792.

Nesta. (2014). Challenge Prizes: A Practice Guide.

Oliveira, L. S. de, Echeveste, M. E. S., Cortimiglia, M. N., \& Gonçalves, C. G. C. (2017). Analysis of determinants for Open Innovation implementation in Regional Innovation Systems. RAI Revista de Administração e Inovação, 14 (2), 119-129.

Parida, V., Westerberg, M., \& Frishammar, J. (2012). Inbound Open Innovation Activities in 
High-Tech SMEs: The Impact on Innovation Performance. Journal of Small Business Management, 50(2), 283-309.

Patton, M. Q. (1999). Enhancing the quality and credibility of qualitative analysis. Health Services Research, 34(5 Pt 2), 1189-1208.

Pauwels, C., Clarysse, B., Wright, M., \& Van Hove, J. (2016). Understanding a new generation incubation model: The accelerator. Technovation, 50-51(July 2019), 13-24.

Peffers, K., Tuunanen, T., Rothenberger, M. A., \& Chatterjee, S. (2007). The Design Science Research Process: a Model for Producing and Presenting Information System Research. Journal of Management Information Systems, 3, 45-77.

Piller, F., \& Walcher, D. (2006). Toolkits for idea competitions: A novel method to integrate users in new product development. RED Management, 36(3), 307-318.

Rodriguez Ferradas, M. I., Alfaro Tanco, J. A., \& Sandulli, F. (2017). Relevant factors of innovation contests for SMEs. Business Process Management Journal, 23(6), 1196-1215.

Scotchmer, S. (2006). Innovation and Incentives. The MIT Press.

Sein, M. K., Henfridsson, O., Purao, S., Rossi, M., \& Lindgren, R. (2011). Action Design Research. MIS Quarterly: Management Information Systems, 35(1), 37-56.

Silverman, D. (2019). Interpreting qualitative data. Sage Publications Limited.

Stoltzfus, A., Rosenberg, M., Lapp, H., Budd, A., Cranston, K., Pontelli, E., Oliver, S., \& Vos, R. A. (2017). Community and Code: Nine Lessons from Nine NESCent Hackathons. F1000Research, 6(0), 786.

Strauss, A., \& Corbin, J. (1994). Grounded theory methodology. Handbook of Qualitative Research, 17, 273-285.

Terwiesch, C., \& Xu, Y. (2008). Innovation contests, open innovation, and multiagent problem solving. Management Science, 54 (9), 1529-1543.

Tödtling, F., \& Trippl, M. (2005). One size fits all?: Towards a differentiated regional innovation policy approach. Research Policy, 34 (8), 1203-1219.

Tong, R., \& Lakhani, K. R. (2012). Public-Private Partnerships for Organizing and Executing Prize-Based Competitions. In The Berkman Center for Internet $E$ Society at Harvard University (Issue 13).

Usman, M., Roijakkers, N., Vanhaverbeke, W., \& Frattini, F. (2018). A systematic review of the literature on open innovation in SMEs. In Researching Open Innovation In SMEs (pp. $3-35)$.

Van Maanen, J. (1979). Reclaiming Qualitative Methods for Organizational Research: A Preface. Administrative Science Quarterly, 24(4), 520-526.

Weiblen, T., \& Chesbrough, H. W. (2015). Engaging with startups to enhance corporate innovation. California Management Review, 57(2), 66-90. 
West, J., \& Bogers, M. (2014). Leveraging external sources of innovation: A review of research on open innovation. Journal of Product Innovation Management, 31(4), 814-831.

Williams, H. (2012). Innovation inducement prizes: connecting research to policy. Journal of Policy Analysis and Management, 31(4), 752-776.

Zahra, S. A., \& George, G. (2002). Absorptive Capacity: A Review, Reconceptualization, and Extension. Academy of Management Review, 27(2). 


\section{Biographies}

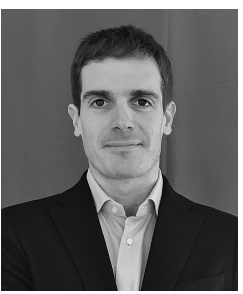

Nicola Doppio. Born in Italy in 1981, Nicola holds a Master's degree in Sociology (University of Trento, 2006), and an EMIM - Executive Master in Management from MIP - Politecnico di Milano, School of Business (2018). Nicola has a 10-year experience in designing and managing multi-stakeholders research, innovation and consultancy projects in the field of business administration, total quality management, technology $\mathrm{R} \& \mathrm{D}$, new product development, service design and innovation management. He currently works at Hub Innovazione Trentino (Trento, Italy) as an Innovation Officer, designing and managing European projects and regional initiatives fostering research-industry Open Innovation. He also trains start-ups and researchers on topics such as user-centered design, service-design, new product development and innovation strategies, lean start-up method. Previously, Nicola has managed EU-wide Living Lab projects involving leading digital corporates, universities and research centres in the co-design and real-life test of hi-tech digital products and concepts involving citizens in technology innovation and citizens' science projects.

CRediT Statement: Conceptualization, Methodology, Investigation, Formal analysis, Writing - Original draft preparation, Writing - Review \& Editing, Supervision, Project administration, Funding acquisition.

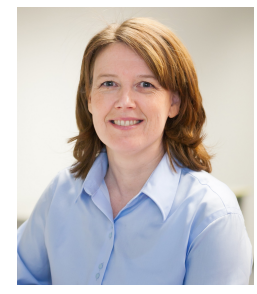

Satu Väinämö. Satu J. Väinämö, received M.Sc. degree in industrial engineering and management from University of Oulu, Finland, in 1991. Her career includes over 15 years in the ICT industry in several leadership positions. Since 2012 she has been working at the University of Oulu, Finland. 2012-2015 she led the international eHealth startups acceleration programme, which accelerated European small and mid-sized enterprises and startups to develop innovative application and businesses in eHealth market. 2016 - 2018 she was director of Oulu Urban Living Labs, in which she was in charge of innovation and living lab related services leading 100+ development activities. Since 2018 she has been building and developing a national research and innovation knowledge Hub, Digihealth Hub, (https://www.oulu.fi/cht/digihealthhub ) and its innovation ecosystem collaboration.

CRediT Statement: Conceptualization, Methodology, Investigation, Formal analysis, Data curation, Visualization, Writing- Original draft preparation, Writing - Review $\& 6$ Editing.

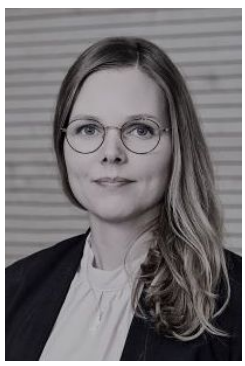

Lotta Haukipuro. Lotta Haukipuro received her doctoral degree in 2019 at Oulu Business School, University of Oulu, Finland. Her research has focused on user involvement through living lab approach in different contexts. She has worked in several national and international living lab and user involvement related RDI projects since 2011. Currently she is a coordinator of the Generation $\mathrm{Z}$ and beyond: Co-evolution of human capabilities and intelligent technologies in the 21st century (GenZ) programme at the University of Oulu.

CRediT Statement: Conceptualization, Methodology, Writing-Original draft preparation, Writing - Review \& Editing.

\section{ISSN 2183-0606}

http://www.open-jim.org

http://creativecommons.org/licenses/by/3.0 